\title{
SEMIOTIKA KOMUNIKASI VISUAL PADA KAMPANYE MEDIA DARING ORGANISASI DIFABEL AKAR TULI
}

\author{
Angga Kusuma Dawami \\ Program Studi Desain Komunikasi Visual, Universitas Indraprasta PGRI
}

\begin{abstract}
Abstrak. Organisasi difabel menciptakan produk-produk kampanye media daring yang diproduksi guna membantu komunikasi visual mereka untuk mencapai tujuan organisasinya. Akar Tuli merupakan salah satu organisasi difabel Tuli yang menggunakan sosial media pada media daring untuk mempublikasikan karya-karya kampanyenya. Tulisan ini membahas tentang bagaimana semiotika komunikasi visual dari kampanye digital yang dilakukan oleh Akar Tuli. Dengan menggunakan pendekatan semiotika, dan analisis semiotika komunikasi visual, karya-karya kampanye digital Akar Tuli mampu diklasifikasikan berdasarkan tanda, kode, dan makna yang terkandung di dalamnya. Penelitian ini menunjukkan bahwa bahwa ketiga iklan yang telah dibahas dalam tulisan dengan menggunakan semiotika komunikasi visual menunjukkan adanya kode-kode kebudayaan, simbolik, dan narasi dalam menampilkan poster digital mereka. Wacana-wacana yang mendalam dari kampanye media daring yang telah dipaparkan belum menunjukkan kedalaman materi yang diangkat dalam kampanye. Hanya sebagai sebuah peringatan hari besar, atau sebuah momen, atau hanya sebagai undangan terbuka. Produksi iklan yang berperan sebagai tanda, dapat dilihat sebagai sebuah gejala komunikasi visual yang dapat dibaca serta ditafsirkan guna menjadi sebuah ilmu pengetahuan untuk komunitas difabel itu sendiri atau masyarakat lebih luas. Selain itu juga membuktikan bahwa difabel tidak hanya sekedar menjadi obyek charity, namun menjadi subyek yang juga berperan dalam masyarakat secara luas
\end{abstract}

Kata Kunci: Semiotika, Komunikasi Visual, Difabel, Akar Tuli

Abtract. Diffable organizations create online media campaign products that are produced to help their visual communication to achieve their organizational goals. Akar Tuli is one of the Deaf's organizations that uses social media on online media to publish their campaign works. This paper discusses how the semiotics of visual communication from digital campaigns carried out by Akar Tuli. By using a semiotic approach, and semiotic analysis of visual communication, digital campaign works of Deaf Root are able to be classified based on signs, codes, and meanings contained therein. This study shows that the three advertisements discussed in the paper using visual communication semiotics show the existence of cultural, symbolic, and narrative codes in displaying their digital posters. In-depth discourses from online media campaigns that have been described have not yet shown the depth of the material raised in the campaign. Only as a memorial to a holiday, or a moment, or just as an open invitation. Production of advertisements that act as signs, can be seen as a symptom of visual communication that can be read and interpreted to become a science for the diffable community itself or the wider community. In addition, it also proves that disabled people are not merely objects of charity, but are subjects that also play a role in society at large

Keywords: Semiotics, Visual Communication, Disabled, Akar Tuli

Correspondence author: Angga Kusuma Dawami, akdawami@gmail.com, Jakarta, Indonesia 


\section{PENDAHULUAN}

Kajian Desain Komunikasi Visual-yang kemudian dalam tulisan ini akan menggunakan kata DKV - memproduksi obat pembius untuk para target marketnya. Tinarbuko (2) menyatakan bahwa periklanan dalam konteks desain komunikasi visual adalah fenomena bisnis modern, tidak ada perusahaan yang ingin maju dan memenangkan kompetisi bisnis tanpa mengandalkan iklan. Meskipun begitu, DKV tidak hanya berkutat pada organisasi atau entitas yang berorientasi pada profit saja. DKV perlu melihat juga bagaimana organisasi-organisasi non-profit atau organisasi sosial dalam menggunakan komunikasi visual sebagai sebuah usaha untuk mencapai tujuan organisasi tersebut. Biasanya berkutat pada advokasi, pendidikan kepada masyarakat, serta iklan layanan masyarakat. Iklan bukan semata-mata pesan bisnis yang hanya berbicara usaha mencari keuntungan secara sepihak, iklan juga mempunyai peran yang sangat benting bagi pelbagai kegiatan nonbisnis (Tinarbuko 36). Perjuangan advokasi kelompok difabel juga memerlukan merek yang kuat (Dawami et al. 2). Bentuk-bentuk advokasi dalam kajian Desain Komunikasi Visual memang membutuhkan pembangunan merek yang kuat.

Media-media untuk menanam iklan yang begitu beragam memberikan kesempatan yang luas bagi organisasi non-profit dalam melakukan kampanyenya. Dengan media sosial, hampir semua organisasi non-profit melakukan kampanyenya melalui media daring dan media sosial daring. Harga yang dibayar tidak seperti media-media konvensional, yang notabene membutuhkan banyak biaya untuk menyewa sebuah baliho atau tempat. Pada hakikatnya, dalam konteks DKV, iklan dapat menjadi simbol sejauh imaji yang ditampilkannya membentuk dan merefleksikan nilai-nilai hakiki (Tinarbuko 3). Iklan-iklan yang didesain akan menunjukkan bagaimana sebenarnya sebuah entitas itu. Dengan spirit tanpa batas, seorang desainer pada sebuah entitas, menyelami dan lebur dengan entitas diluarnya (Rahayu 160).

Pembentukan nilai-nilai dari tujuan organisasi non-profit berakar pada bagaimana dia merefleksikan visi dan misinya untuk menyampaikannya kepada masyarakat. Dari dulu hingga akhir hayat, masyarakat tetap membutuhkan iklan sebagai sumber informasi atas keberadaan produk dan jasa yang mampu meningkatkan harkat hidup orang banyak (Tinarbuko 36). Seperti organisasi difabel, kebanyakan, mengangkat nilai-nilai hak asasi manusia dalam iklan-iklannya. Mereka menggunakan isu kesetaraan hak antar masyarakat non-difabel dengan masyarakat difabel secara masif dalam setiap kampanyenya. Contoh seperti Akar Tuli, yang merupakan organsasi difabel Tuli yang berbasis di Malang. Mereka menggunakan media sosial untuk mengkampanyekan adanya mereka, memberikan informasi kepada khayalak bahwa mereka ada di masyarakat. Akar Tuli telah menggunakan logo yang konsisten untuk mengkampanyekan usaha advokasi mereka sesuai dengan kebutuhan dan tujuannya (Dawami 139).

Akar Tuli (Aksi Arek Tuli Malang), merupakan organisasi Tuli yang berbasis di Malang, Jawa Timur, fokus pergerakannya adalah penyebaran bahasa Isyarat kepada masyarakat umum. Kegiatan utamanya adalah advokasi difabel Tuli untuk mengusahakan kesetaraan sesuai dengan UU no 8 tahun 2016 tentang Penyandang Disabilitas. Bahwa Tuli juga harus terjembatani aksesibilitasnya. Hal ini yang membuat Akar Tuli menggunakan media daring untuk melakukan kampanye. Selain itu media daring memberikan keterbukaan informasi yang tiada batas. Tidak seperti media-media konvensional yang mengedepankan biaya ceta yang besar serta penempatan yang membutuhkan waktu dan tempat yang tidak sedikit, sedangkan media daring hanya memerlukan ponsel genggam pintar untuk menuggah ke media daring melalui kemampuan internet dalam ponsel pintar. 


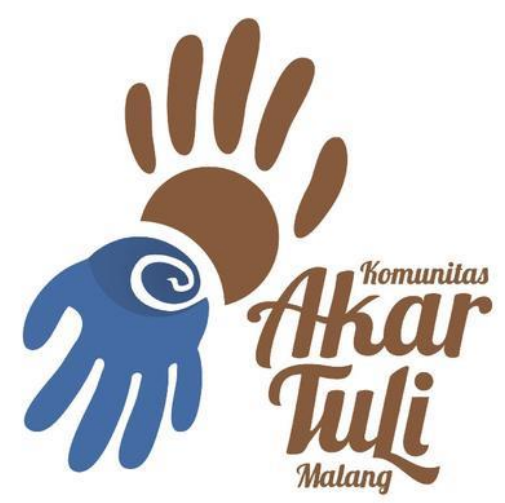

Gambar 1 Logo Akar Tuli Malang (dok. Daring Akar Tuli, 2017)

Kampanye-kampanye yang diproduksi Akar Tuli pada media daring merupakan sebuah tanda yang memuat pesan-pesan untuk masyarakat secara umum. Artinya, sebuah tanda (berwujud kata atau gambar) mempunyai dua aspek yang ditangkap oleh indra yang disebut signifier, bidang penanda atau bentuk, yang kedua adalah signified, bidang petanda atau konsep atau makna (Tinarbuko 13)

Kampanye-kampanye Akar Tuli di media daring ini menarik untuk dilihat, bagaimana sebenarnya mereka menggunakan komunikasi visual untuk melakukan pengenalan organisasi mereka ke masyarakat secara luas. Melalui media sosialnya, tulisan ini membedah karya-karya komunikasi visual yang diproduksi oleh Akar Tuli untuk melakukan advokasi maupun pengenalan dirinya atau memberikan peringatan terhadap hari-hari besar.

\section{PEMBAHASAN}

\section{Landasan Teori}

Semiotika Komunikasi Visual

Melalui pendekatan teori semiotika, diharapkan karya DKV mampu diklasifikasikan berdasarkan tanda, kode dan makna yang terkandung di dalamnya (Tinarbuko 9). Pesan-pesan DKV yang disampaikan Akar Tuli kepada khayalak dapat menjadi tolak ukur bagaimana Akar Tuli melakukan kampanyenya di media daring.

Karena menyasar ke khayalak, maka DKV disosialisasikan melalui tanda. Menurut Tinarbuko, tanda terbagi menjadi dua, pertama tanda verbal didekati pada aspek ragam bahasa, tema, dan pengertian yang didapatkan. Sedangkan kedua adalah tanda visual, yang dilihat dari cara menggambarkannya, apakah secara ikonis, indeksial, atau simbolis, dan bagaimana cara mengungkapkan idiom. Tanda-tanda yang telah dilihat dan dibaca dari dua aspek secara terpisah, kemudian diklasifikasikan, dan dicari hubungan antara yang satu dengan lainnya (Tinarbuko 10).

\section{Tanda (Ikon, Indeks, Simbol)}

Menurut Tinarbuko (16-17), Ikon adalah tanda yang mirip dengan boyek yang diwakilinya. Contohnya, foto Soekarno sebagai Bapak Proklamator adalah ikon kemerdekaan Indonesia. Sedangkan Indeks merupakan tanda yang memiliki hubungan sebab akibat dengan apa yang diwakili, atau disebut juga tanda sebagai bukti. Perbedaan dengan simbol adalah tanda berdasarkan konvensi, peraturan, atau perjanjian yang disepakati bersama. 
Kode

Menurut Pialang dalam Tinarbuko (17-18) adalah cara mengkombinasi tanda yang disepakati secara sosial untuk memungkinkan satu pesan disampaikan dari seseorang ke orang lain. Dalam perihal analisis semiotika visual, Tinarbuko mengacu pada Barthes dalam buku S/Z mengelompokkan kode-kode menjadi lima kisi-kisi kode. Dan dijelaskan Pradopo dalam Tinarbuko, berpa:

1. Kode Hermeneutik

Artikulas pelbagai cara pertanyaan, teka-teki, respons, enigma, pengangguhan jawaban, akhirnya menuju jawaban. Atau dengan kata lain, kode hermeneutik berhubungan dengan teka-teki yang timbul dalam sebuah wacana

2. Kode Semantik

Kode yang mengandung konotasi pada level penanda, atau dengan kata lain, kode semantik adalah tanda-tanda yang ditata sehingga memberikan suatu konotasi maskulin, feminim, kebangsaan, kesukuan, atau loyalitas.

3. Kode Simbolik

Kode yang berhubungan dengan psikoanalisis, antitesis, kemenduaan, pertentangan dua unsur, atau skizofrenia.

4. Kode Narasi

Yaitu kode yang mengandung cerita, urutan, narasi, atau antinarasi

5. Kode Kultural/Budaya

Merupakan suara-suara yang bersifat kolektif, anomin, bawah sadar, mitos, kebijaksanaan, pengetahuan, sejarah, moral, psikologi, sastra, seni dan legenda.

\section{Makna Denotatif dan Konotatif}

Makna Denotatif menurut Spradley dalam Tinarbuko (19), makna denotataif meliputi hal-hal yang ditunjuk oleh kata-kata (makna referensial). Sedangkan menurut Piliang, makna denotatif hubungan eksplisit antara tanda dengan referensi atau realitas dalam pertandaan tahap denotatif. Misalkan ada gambar manusia, pohon, warna yang digunakan apa. Pada tahap ini, hanya informasi data yang disampaikan.

Makna Konotatif menurut Spradley dalam Tinarbuko meliputi semua sigifikasi sugestif dari simbol yang lebih daripada arti referensialnya. Sedangkan menurut Piliang, makna konotatif meliputi aspek makna yang berkaitan dengan perasaan dan emosi serta nilai-nilai kebudayaan dan ideologi. Contohnya apabila ada gambar wajah orang cemberut dapat diartikan sebagai suatu kegelisahan, kesedihan. Namun bisa saja cemberut diartikan sebagai ekspresi kesenangan karena bercanda oleh orang lain.

\section{Analisis Komunikasi Visual}

Akar Tuli memproduksi komunikasi visual melalui poster yang dapat dianalisis menggunakan semiotika komunikasi visual. Ada 3 poster yang diambil secara acara dari media sosial di daring secara acak, guna melihat bagaimana Akar Tuli membuat iklan mereka di media daring instagram @akartuli. 


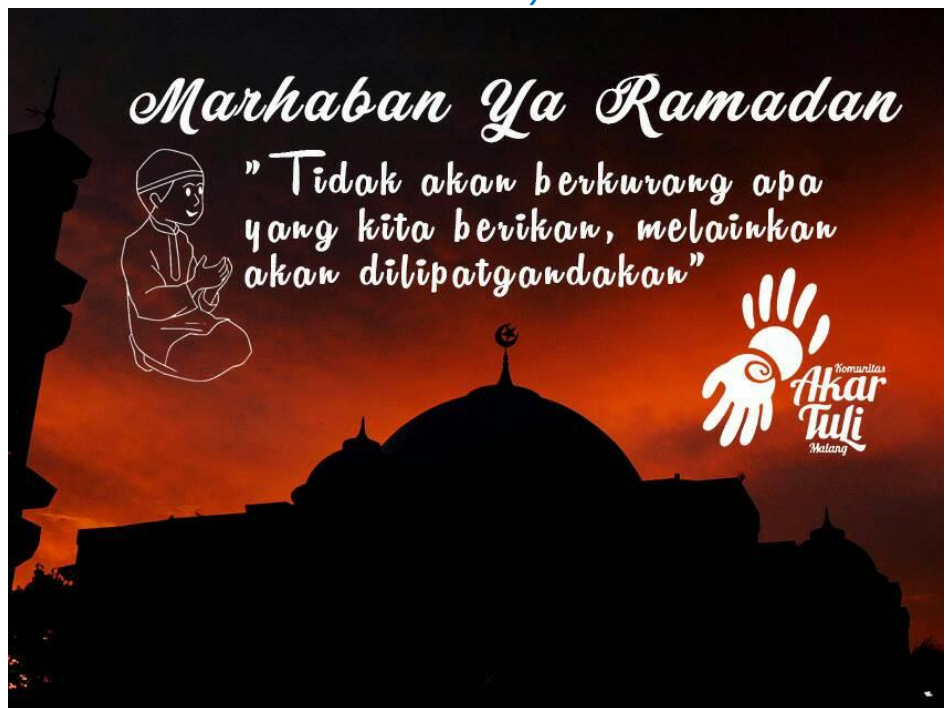

Gambar 2 Poster Akar Tuli untuk mengucapkan Selamat Ramadhan (dok. Daring Akar Tuli, 2017)

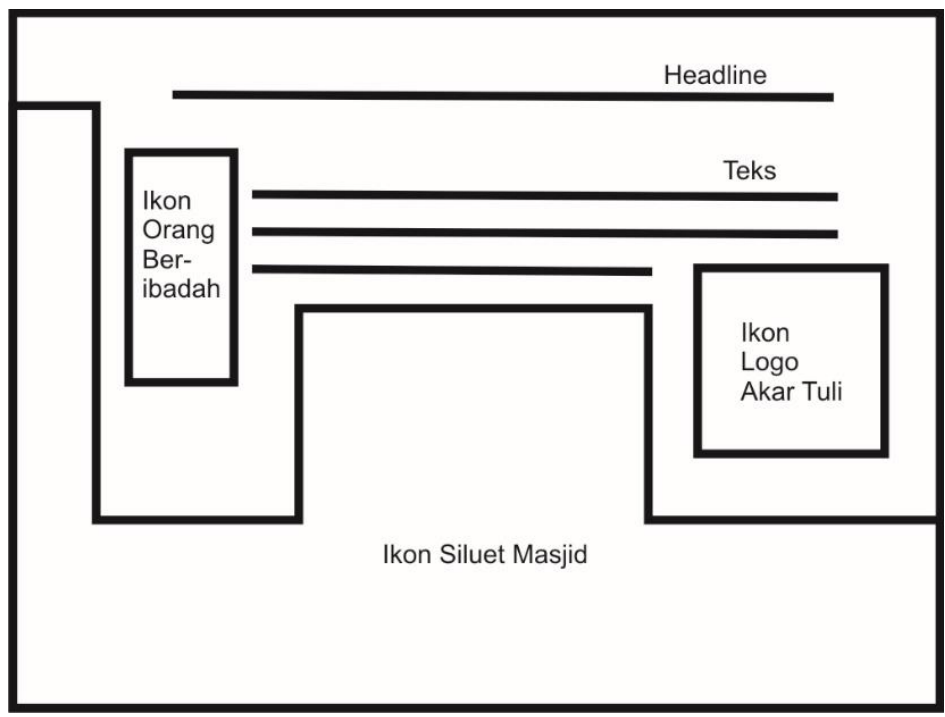

Gambar 3 Layout Poster Marhaban Ramadhan Akar Tuli Malang (dok. Pribadi, 2017)

1. Tanda Verbal

a. Teks

Marhaban Ya Ramadan

Tidak akan berkurang apa yang kita berikan, melainkan akan dilipatgandakan.

b. Tanda Visual

Ilustrasi dalam poster digital ini menggunakan tiga ikon; pertama, ikon orang sedang beribadah; kedua, ikon siluet masjid yang memenuhi hampir setengah poster; dan ketiga, ikon logo Akar Tuli yang merepresentasikan bahwa poster ini dari Akar Tuli.

2. Analisis Semiotika Komunikasi Visual

Berdasarkan tanda verbal dan tanda visual tersebut, pesan poster diatas dapat ditangkap dengan bantuan kode simbolik dan kode kebudayaan. Kode simbolik ditunjukkan 
dengan diskripsi yang cukup jelas tentang "Tidak akan berkurang apa yang kita berikan melainkan akan dilipatgandakan." Dimana pada bulan Ramadan banyak orang yang fokus terhadap beribadah, dan dipercaya akan dilipatgandakan apa yang diberikan keluar dirinya.

Kode kebudayaan terlihat dari ikon-ikon yang berhubungan dengan suasana ramadan, berupa masjid yang ditunjukkan dengan ikon siluet masjid. Dalam poster ini, mengusung tema ramadahan yang kental dengan ikon masjid dan orang sholat. Dengan demikian, terhadap hubungan erat antara tanda verbal dalam bentuk teks dan tanda visual berupa konfigurasi masjid, dan orang berdoa. Pesan yang muncul adalah ajakan untuk memberi, dengan percaya semakin kita memberi, maka akan melipagandakan.

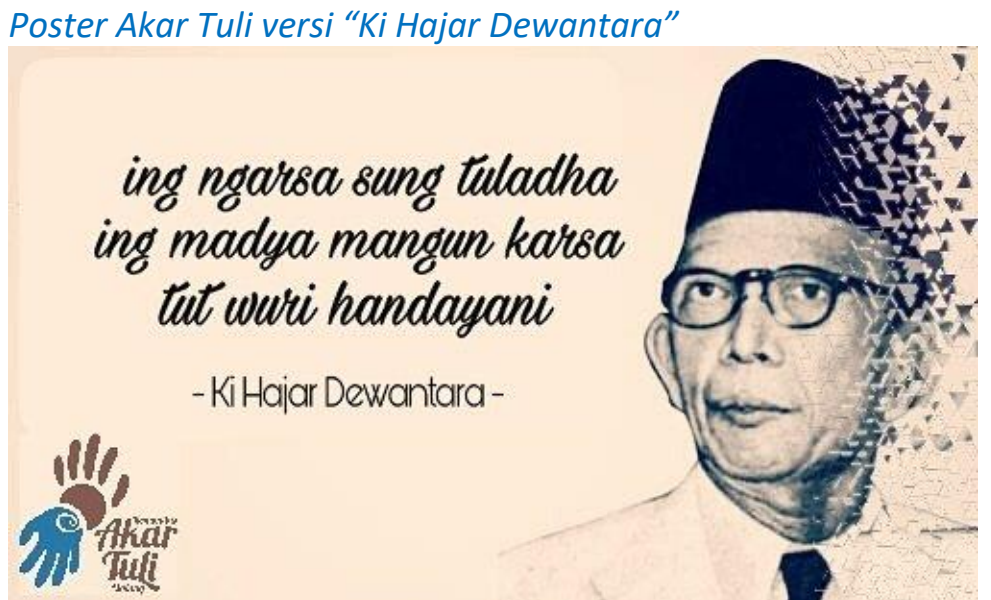

Gambar 4 Poster Akar Tuli versi Ki Hajar Dewantara (dok. Daring Akar Tuli, 2017)

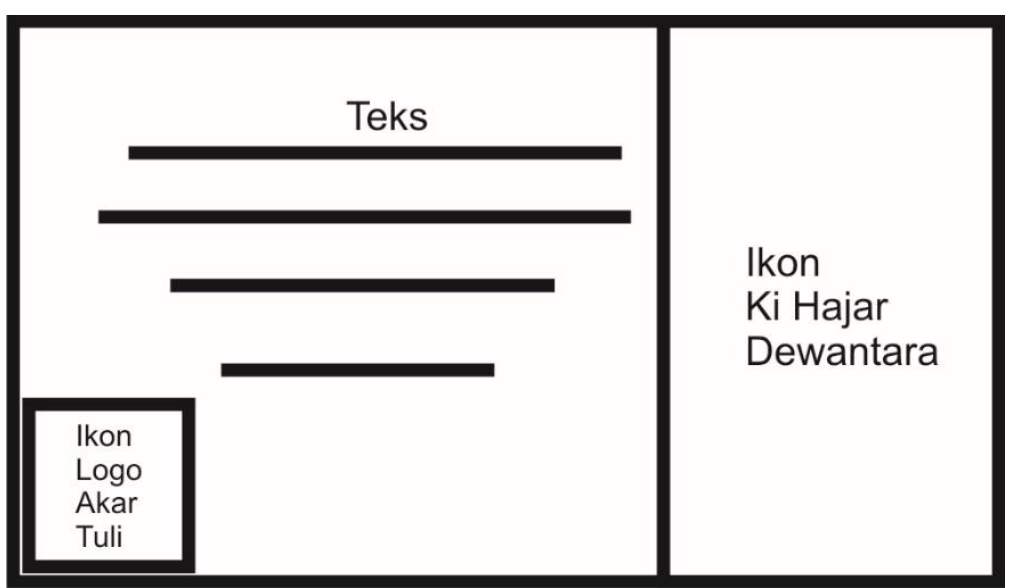

Gambar 5 Layout Poster Akar Tuli versi Ki Hajar Dewantara (dok. Pribadi, 2017)

1. Tanda Verbal

a. Teks

Ing ngarso sung tuladha, ing madya mangun karsa, tut wuri handayani.

Ki Hajar Dewantara

b. Tanda Visual

Ilustrasi dalam poster digital ini menggunakan ilustrasi wajah Ki Hajar Dewantara, dan ikon logo Akar Tuli 
2. Analisis Semiotika Komunikasi Visual

Poster ini menunjukkan keterhubungan antara teks dengan tanda visual yang ditampilkan dalam bidang gambar. Ilustrasi yang menggunakan wajah Ki Hajar Dewantara memberikan kesan bahwa memang yang berkata dalam poster tersebut adalah Ki Hajar Dewantara. Dapat dikatakan, ia lebih bersifat ikonik.

Kode visual narasi ditunjukkan dengan adanya keterhubungan antara teks dengan tanda visual. Ilustrasi seakan-akan berkata "ing ngarso sung tuladha, ing madya mangun karsa, tut wuri handayani" yang berarti menjadi seorang pemimpin (ngarso) harus mampu memberikan suri tauladan bagi orang - orang disekitarnya. Sehingga yang harus dipegang teguh oleh seseorang adalah kata suri tauladan. Seseorang ditengah (madya) kesibukannya harus juga mampu membangkitkan atau menggugah semangat. Dan seseorang harus memberikan dorongan (tut wuri) moral dan semangat kerja dari belakang. Dorongan moral ini sangat dibutuhkan oleh orang - orang disekitar kita menumbuhkan motivasi dan semangat.

Ki Hajar Dewantara merupakan salah satu Pahlawan Nasional yang bergerak dalam bidang Pendidikan. Pesan-pesannya sering digunakan oleh banyak institusi sebagai inspirasi dalam menjalani kehidupan. Termasuk salah satunya adalah Akar Tuli yang menggunakan teks dari Ki Hajar Dewantara yang dikemas dalam poster yang dikeluarkan pada hari pendidikan nasional.

Dalam kode kebudayaan, poster ini memiliki isi pengetahuan yang sesuai dengan apa yang disampaikan Ki Hajar Dewantara. Hubungan antara kebudayaan dengan narasi ilustrasi visual memiliki keterkaitan yang kuat. Pesan yang dibawa dalam poster ini adalah semua lapisan masyarakat hendaknya kembali menilik apa yang dikatakan oleh Ki Hajar Dewantara, tentang memimpin, yang dipimpin, dan orang-orang yang mendukungnya.

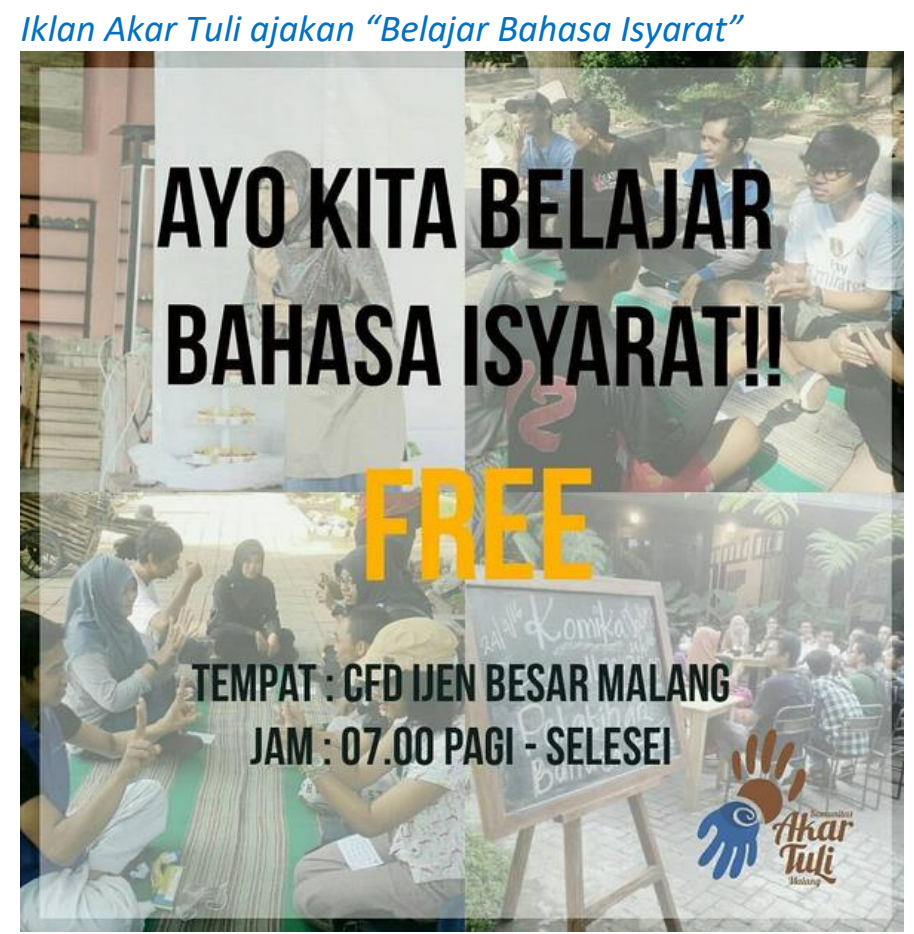

Gambar 6 Poster ajakan Kelas Isyarat(dok. Daring Akar Tuli, 2017) 


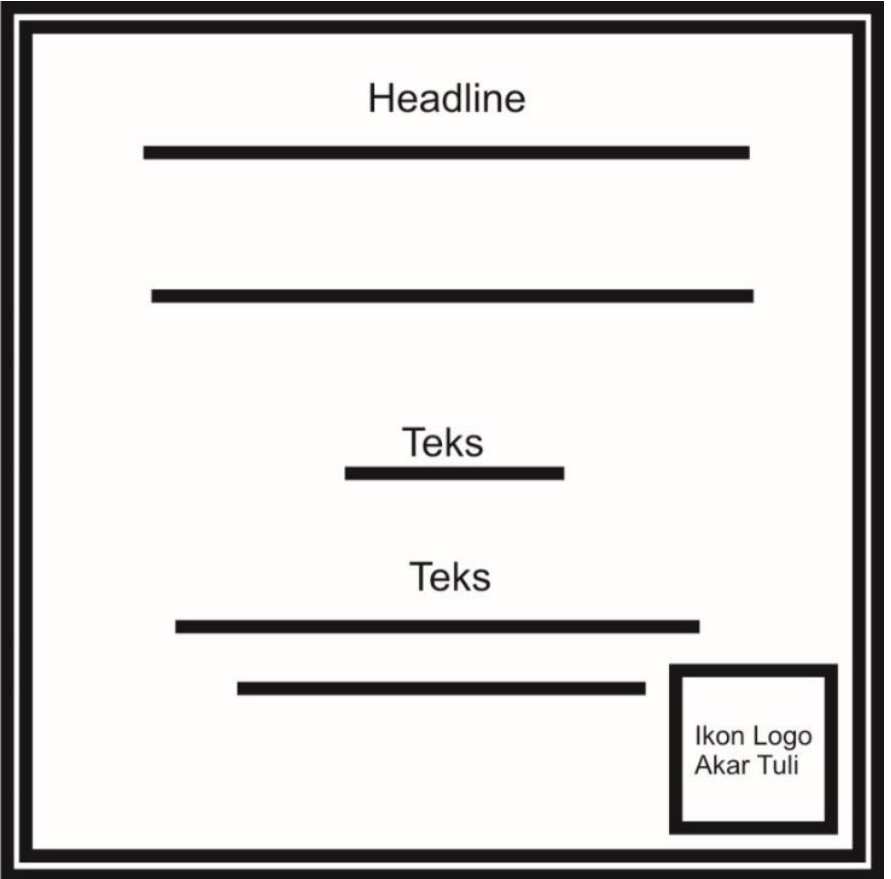

Gambar 7 Layout Poster ajakan Kelas Isyarat (dok. Daring Akar Tuli, 2017)

1. Tanda Verbal

a. Teks

Ayo Kita Belajar Bahasa Isyarat!!

Free

Tempat: CFD Ijen Besar Malang

Jam: 07.00 Pagi - Selesai

b. Tanda Visual

Ilustrasi dalam poster digital ini menggunakan 4 foto kegiatan yang diberikan efek blur. Selain itu, menggunakan ikon logo Akar Tuli

2. Analisis Semiotika Komunikasi Visual

Berdasarkan tanda verbal dan tanda visual tersebut, memuat kode narasi teks dan kode simbolik. Narasi teks ditunjukkan dengan adanya keterkaitan kegiatan apa yang akan diadakan, dimana tempatnya, dan waktu akan berlangsungnya kegiatan.

Kode simbolik terlihat dari gambar sebagai latar yang ditunjukkan dengan adanya kegiatan-kegiatan bagaimana kelas isyarat. Selain itu ditunjukkan dengan adanya simbol visual logo Akar Tuli.

Ajakan ini merupakan salah satu kegiatan rutin Akar Tuli untuk membuka kelas Isyarat di wilayah Malang dan sekitarnya. Akar Tuli menggunakan komunikasi visual melalui daring dengan undangan secara terbuka seperti poster tesebut. Pesan yang disampaikan dalam poster ini adalah usaha yang dilakukan Akar Tuli menunjukkan bahwa kampanye untuk aksesibilitas Tuli dibuka seluas-luasnya untuk masyarkat umum. Dapat diikuti oleh setiap orang yang melihat poster atau diajak oleh Tuli dari Akar Tuli itu sendiri. 


\section{PENUTUP}

Produksi komunikasi visual oleh Akar Tuli membuktikan bahwa banyak hal yang dilakukan organisasi non-profit, lebih khusus difabel, dalam perjuangan untuk membangun mereknya. Produksi iklan yang berperan sebagai tanda, dapat dilihat sebagai sebuah gejala komunikasi visual yang dapat dibaca serta ditafsirkan guna menjadi sebuah ilmu pengetahuan untuk komunitas difabel itu sendiri atau masyarakat lebih luas. Selain itu juga membuktikan bahwa difabel tidak hanya sekedar menjadi obyek charity, namun menjadi subyek yang juga berperan dalam masyarakat secara luas.

Ketiga iklan yang telah dibahas dengan menggunakan semiotika komunikasi visual menunjukkan adanya kode-kode kebudayaan, simbolik, dan narasi dalam menampilkan poster digital mereka. Wacana-wacana yang mendalam dari poster yang telah dipaparkan belum menunjukkan kedalaman materi yang diangkat. Hanya sebagai sebuah peringatan hari besar, atau sebuah momen, atau hanya sebagai undangan terbuka. Perlu ada penelitian yang membahas tentang pembangunan wacana yang dapat digunakan oleh Akar Tuli untuk membentuk konstruksi sesuai dengan tujuan organisasi.

\section{DAFTAR PUSTAKA}

Dawami, Angga Kusuma. "Logo Sebagai Komunikasi Visual Dari Identitas Organisasi Difabel Tuli." Magental Official Journal STMK Trisakti, vol. 1, no. 02, 2017, pp. 133-141, http://magenta.trisaktimultimedia.ac.id/magenta/index.php/magenta/article/view/14

Dawami, Angga Kusuma et al. "Analisis Kampanye Hari Disabilitas Internasional (Hdi) Tahun 2017 Kabupaten Klaten." Jurnal Desain, vol. 6, no. 01, 2019, pp. 1-9, doi:http://dx.doi.org/10.30998/jurnaldesain.v6i01.2620.

Rahayu, Sri. Untuk Apa Seni? Pada Artikel Desain Dan Ruhnya Kini. Matahari, 2014.

Tinarbuko, Isidorus Tyas Sumbo. Dekave: Desain Komunikasi Visual Penanda Zaman Masyarakat Global. CAPS, 2015.

Tinarbuko, Sumbo. Semiotika Komunikasi Visual: Metode Analisis Tanda Dan Makna Pada Karya Desain Komunikasi Visual. Jalasutra, 2009. 